\title{
Influence of temperature and time during malaxation on fatty acid profile and oxidation of centrifuged avocado oil
}

\author{
Jessica del Pilar RAMÍREZ-ANAYA ${ }^{1 *}$, Ariana Jocelyn MANZANO-HERNÁNDEZ1 ${ }^{1}$ Ernesto TAPIA-CAMPOS², \\ Karina ALARCÓN-DOMÍNGUEZ ${ }^{3}$, Ma Claudia CASTAÑEDA-SAUCEDO ${ }^{4}$
}

\begin{abstract}
Virgin oil from avocados (Persea americana Mill.) is obtained by mechanical processes after pulp malaxation at temperatures that minimize oxidation and improve separation. The objective of this study was to assess the effect of time $(0,20,30,40,60,120$ and $180 \mathrm{~min})$ and temperature $\left(40\right.$ and $50^{\circ} \mathrm{C}$ ) conditions during pulp malaxation on extraction yield, nutritional value (normalized fatty acid profile) and specific extintion (K232 and K270) of virgin oil extracted under laboratory conditions from avocados cultivated in southern Jalisco, Mexico. When pulp was malaxated for $120 \mathrm{~min}$ at 40 and $50^{\circ} \mathrm{C}$, a larger proportion of oil was extracted $(82.9 \pm 0.3 \%$ and $80.2 \pm 0.8 \%$, respectively). We observed that the normalized percentage of the fatty acids linoleic $(18 \pm 2 \%)$ and linolenic $(1.2 \pm 0.2 \%)$ decreased with mixing time, while that of palmitoleic $(9 \pm 1 \%)$, oleic $(51.6 \pm 1.2 \%)$ and stearic $(0.5 \pm 0.1 \%)$ remained without change. The $\omega-6: \omega-3$ ratio $(15 \pm 1)$ was higher than the recommended values but similar to those reported as favorable for health. Specific extinction $\left(\mathrm{K}_{232,}, 2.2 \pm 0.3\right.$ and $\left.\mathrm{K}_{270}, 0.20 \pm 0.03\right)$ indicate that the oxidation level remained low. Malaxation at 40 or $50^{\circ} \mathrm{C}$ did not significantly alter the characteristics of the oil, but time significantly affected yield.
\end{abstract}

Keywords: essential fatty acid; fatty acids; linoleic:palmitic ratio; oil yield; oxidation.

Practical Application: Describe the malaxation conditions for avocado pulp that give higher extraction of good quality oil.

\section{Introduction}

Mexico is the largest producer of avocado (Persea americana Mill.) worldwide. Today, around 70 species of the genus Persea are distributed in the temperate regions of America, while in East and Southeast Asia there are 80 species (Ding et al., 2007). "Hass" is the variety most cultivated because it is highly productive and its fruit has favorable characteristics; for example, its oil contents can reach 55\% (Oliveira et al., 2013). Most of the production is sold for fresh consumption and only $10 \%$ is used as raw material in the production of processed food. Avocado oil is one of its main products promoted as a gourmet food. Its fatty acid (FA) profile exhibits 80 to $85 \%$ unsaturated FA (mainly oleic and linoleic). This lipid profile has been associated with technological characteristics such as stability at frying temperature $\left(180^{\circ} \mathrm{C}\right)$, which makes it appropriate for cooking, for making dressings or for fabrication of margarines (Meyer \& Terry, 2008; Restrepo et al., 2012).

This oil has been classified as "healthy", together with almond, hazelnut and macadamia oil, which have a lipid profile rich in monounsaturated fat like that of olive oil (Kochhar \& Henry, 2009). The polyunsaturated/saturated FA ratio and that of $\omega-3: \omega-6$ in avocado oil is even higher than olive oil (Berasategi et al., 2012). Because of its lipid profile, it has preventive effects against cardiovascular accidents and antiatherogenic effects and corrects dyslipidemia by reducing levels of low density lipoproteins (LDL) while increasing high density lipoproteins (HDL) (Alvizouri \&
Rodríguez, 2009). Its composition includes dietary antioxidants such as carotenes, tocopherols and polyphenols, which inhibit growth of prostate cancer cell lines, and sterols, mainly $\beta$-sitosterol, which reduce absorption of cholesterol in the intestine; it is an immune potentiator and has anti-inflammatory effects (Ding et al., 2007).

Cold-pressed avocado oil is that which has been extracted mechanically at temperatures below $50{ }^{\circ} \mathrm{C}$ with no solvents (Woolf et al., 2009). The process begins with peeling and de-stoning the fruit, followed by pulp malaxation, mixing for no more than $90 \mathrm{~min}$ to rupture the sub-cellular compartments that contain the oil. Avocado malaxation conditions are superior to those used in other cases since the oil is more finely dispersed inside the cells. Lipoprotein membranes or lipophilic solids of the paste, which can absorb part of the oil, surround the emulsions formed. For this reason, the process is often facilitated by adding different proportions of water, calcium salts, talcum and acidifiers (hydrochloric or phosphoric acid) with discrete temperature increments, or cellulase, hemicellulase and pectinase enzymes available on an industrial scale (Buelvas et al., 2012; Schwartz et al., 2007). In some cases, the paste is dehydrated before extracting the oil by pressing, centrifuging or decanting (Costagli $\&$ Betti, 2015). With the procedures of centrifuging/pressing, yields are often low (Schwartz et al., 2007) but oil quality is higher since its characteristic color is maintained, the formation of free

${ }^{1}$ Departamento de Ciencias Computacionales e Innovación Tecnológica, Centro Universitario del Sur - UdeG, Ciudad Guzmán, Jalisco, México

${ }^{2}$ Centro de Investigación y Asistencia en Tecnología y Diseño del Estado de Jalisco - CIATEJ, Guadalajara, Jalisco, México

${ }^{3}$ Laboratorio de Tecnología de Alimentos, Instituto Tecnológico de Tamazula, Tamazula de Gordiano, Jalisco, México

${ }^{4}$ Departamento de Ciencias de la Naturaleza, Centro Universitario del Sur - UdeG, Ciudad Guzmán, Jalisco, México

*Corresponding author: jessica@cusur.udg.mx 
and trans FA is kept to a minimum, and oxidation of unsaturated FA is low. These standards are important for prevention or reduction to a minimum of lipid oxidation in edible oils since production and culinary consumption of cold-pressed avocado oil is increasing worldwide (Costagli \& Betti, 2015).

This study assesses the effect of time and temperature conditions during pulp malaxation on extraction yield, FA profile and specific extinctions at 232 and $270 \mathrm{~nm}\left(\mathrm{~K}_{232}\right.$ and $\mathrm{K}_{270}$ ) of virgin oil from avocados (Persea americana Var. Hass) cultivated in southern Jalisco, Mexico.

\section{Materials and methods}

\subsection{Samples}

Fully ripened Persea Americana Mill var. Hass fruits produced in southern Jalisco were acquired in local commercial establishments in Ciudad Guzmán, Jalisco, Mexico, from May to June 2014. All reagents used were analytical grade (Sigma ${ }^{\circledR}$, Missouri, USA).

\subsection{Oil extraction conditions}

The fruits were washed, dried, peeled and de-stoned manually, and pulp weight was recorded. For each trial, the oil was obtained in the laboratory from the pulp of six ripe avocados following an adaptation of the cold extraction procedure described by Ariza et al. (2011) in which the pulp is homogenized with a domestic roller. The pulp was then malaxated manually at $90 \mathrm{rpm}$ in covered glass recipients in a water bath. The recipients were maintained at fixed temperatures $\left(40\right.$ and $\left.50^{\circ} \mathrm{C}\right)$ during six different mixing times $(0,20,30.40,60,120$, and $180 \mathrm{~min})$. Pulp aliquots $(35 \mathrm{~g})$ were centrifuged twice at 15,557 $\mathrm{g}$ for $10 \mathrm{~min}$ (Eppendorf, USA) at ambient temperature. Oil from both centrifugations was combined in dark brown glass bottles, weighed and stored at $-18^{\circ} \mathrm{C}$ until analysis.

\subsection{Fat content}

The fat content of the fresh pulp was determined using the AOAC method 930.09 (Association of Official Analytical Chemists, 2007) and expressed as percentage (\%).

\subsection{Oil yields}

Oil yields obtained during the laboratory extraction treatments described above were expressed as percentage of total fat (\% total fat).

\subsection{Fatty acid profiles}

The fatty acid (FA) normalized composition of crude oil was determined by gas chromatography (GC) after double methylation (Guardiola et al., 1994) of the sample with a $0.5 \mathrm{~N}$ sodium methoxide solution (Sigma, Missouri, USA) followed by $14 \%$ boron trifluoride in methanol (Sigma, Missouri, USA). FA methyl esters (FAME) were recovered in hexane (Sigma, Missouri, USA). FAME was analyzed in a 6820 gas chromatograph (Agilent Technologies, China) equipped with a $50 \mathrm{~m} \times 0.25 \mathrm{~mm}$ id coating cp-sil 88 tailor made FAME capillary column (Varian,
California, USA), and a flame ionization detector. The column temperature was programmed from $60^{\circ} \mathrm{C}(3 \mathrm{~min})$ at $5^{\circ} \mathrm{C} \cdot \mathrm{min}^{-1}$ to $170{ }^{\circ} \mathrm{C}(9 \mathrm{~min})$, at $10^{\circ} \mathrm{C} \cdot \mathrm{min}^{-1}$ to $230(15 \mathrm{~min})$ (the injector and detector temperatures were $230^{\circ} \mathrm{C}$ and $280^{\circ} \mathrm{C}$, respectively). Nitrogen was the carrier gas at a flow rate of $1 \mathrm{~mL} \cdot \mathrm{min}^{-1}$; the split ratio was 1:5. Fatty acids in the oil samples were identified and qualitatively analyzed using the thirty-seven FAME external standard mixture solutions (Supelco FAME mix 37) (Sigma, Bellefonte, Pennsylvania, USA). Results were expressed as percent (\%). Linoleic:linolenic (Massafera et al., 2010) and linoleic:palmitic ratios (Navas, 2007) were calculated from the FA profiles to evaluate, respectively, the lipid nutritional and oxidative quality.

\subsection{Specific extinction}

Avocado oil samples were diluted in cyclohexane UV-Vis (Sigma, Missouri, USA) using the method outlined in COI/T.20/Doc. No 19/Rev. 3 (International Olive Council, 2015). Samples were measured in the UV region at wavelengths of 232 and $270 \mathrm{~nm}$ on a Jenway UV-Vis spectrophotometer (Dunmow, UK) using $1 \mathrm{~cm}$ path length quartz cuvettes with solvent as a blank. Specific extinction (extinction coefficient) was calculated from absorbance, concentration and path length data.

\subsection{Statistical analyses}

All experiments and analyses of the samples were performed in triplicate. The results were expressed as mean \pm standard deviation. The means obtained by the different treatments were compared using ANOVA and the multiple comparisons of means test. The statistical significance level of the study was 0.05. Data analysis was carried out using SPSS for Windows v. 19.

\section{Results and discussion}

\subsection{Fat content}

Initial content of fat in the fresh pulp used in the experiments had values ranging from $17.3 \pm 2.4$ to $19.6 \pm 3.2 \%$ (Table 1 ) These percentages agree with those reported for Hass avocado pulp (16\%) by Villa-Rodríguez et al. (2011) and those cited by Oliveira et al. (2013) for the same variety (21.1\%), and they surpass those quantified by the latter author in other regional varieties such as Ouro Verde (8.5\%), Margarida (8.8\%), Quintal (10.9\%) and Fortuna (6.4\%). The content of oil in avocado pulp is affected by diverse factors, such as variety and climate; however, of these parameters, the degree of ripeness is that of greatest impact. Thus, oil yield improves as the fruit ripens; once the fruits are harvested, the amount of oil does not change (Meyer \& Terry, 2008).

\subsection{Oil yields}

Extraction yield expressed as the proportion of total fat (Table 1) ranged from $0.1 \%$ (control with no malaxation) to $82.9 \%$ $\left(40{ }^{\circ} \mathrm{C}, 120 \mathrm{~min}\right.$ ). These values coincide with those obtained by Schwartz et al. (2007), who reported cold press extraction yields from avocado pulp (Fuerte variety) of 66 to $70 \%$. Our data reveal an increase in this variable in response to temperature 
Table 1. Fat content and oil yield during cold extraction of avocado oil (Persea americana var. Hass) using different malaxation times and temperatures.

\begin{tabular}{|c|c|c|c|}
\hline \multicolumn{2}{|c|}{ Malaxation conditions } & \multicolumn{2}{|c|}{ Yield parameters $^{\mathrm{A}}$} \\
\hline $\begin{array}{c}\text { Temperature } \\
\left({ }^{\circ} \mathrm{C}\right)\end{array}$ & $\begin{array}{l}\text { Time } \\
(\min )\end{array}$ & $\begin{array}{c}\text { Fat content } \\
(\%)\end{array}$ & $\begin{array}{l}\text { Extraction yield } \\
\text { (\% total fat })\end{array}$ \\
\hline \multirow{7}{*}{40} & $\mathbf{0}$ & $18.9 \pm 0.1^{\mathrm{a}}$ & $0.10 \pm 0.01^{\mathrm{a}}$ \\
\hline & 20 & $19.2 \pm 0.7^{\mathrm{a}}$ & $63.9 \pm 1.6^{\mathrm{b}}$ \\
\hline & 30 & $19.1 \pm 0.9^{\mathrm{a}}$ & $69.5 \pm 1.3^{c}$ \\
\hline & 40 & $19.2 \pm 0.7^{\mathrm{a}}$ & $68.1 \pm 0.5^{\mathrm{bc}}$ \\
\hline & 60 & $19.1 \pm 0.9^{\mathrm{a}}$ & $74.3 \pm 0.4^{\text {cde }}$ \\
\hline & 120 & $17.3 \pm 2.4^{\mathrm{a}}$ & $82.9 \pm 0.3^{g}$ \\
\hline & 180 & $19.6 \pm 3.2^{\mathrm{a}}$ & $74.4 \pm 9.6^{\text {de }}$ \\
\hline \multirow{7}{*}{50} & 0 & $18.9 \pm 0.1^{\mathrm{a}}$ & $0.10 \pm 0.01^{\mathrm{a}}$ \\
\hline & 20 & $19.2 \pm 0.7^{\mathrm{a}}$ & $72.6 \pm 1.7^{\text {cde }}$ \\
\hline & 30 & $19.2 \pm 0.7^{\mathrm{a}}$ & $75.6 \pm 0.3^{\text {ef }}$ \\
\hline & 40 & $19.2 \pm 0.7^{\mathrm{a}}$ & $75.1 \pm 0.1^{\mathrm{de}}$ \\
\hline & 60 & $19.1 \pm 0.9^{\mathrm{a}}$ & $77.4 \pm 0.4^{\mathrm{efg}}$ \\
\hline & 120 & $18.3 \pm 2.4^{\mathrm{a}}$ & $80.2 \pm 0.8^{\mathrm{fg}}$ \\
\hline & 180 & $18.3 \pm 2.4^{\mathrm{a}}$ & $70.7 \pm 0.5^{\mathrm{cd}}$ \\
\hline \multicolumn{2}{|c|}{ Mean } & $19.4 \pm 1.3$ & $63.2 \pm 27.2$ \\
\hline
\end{tabular}

f.w.: Fresh weight; ${ }^{A}$ Values are the means \pm SD $(n=3){ }^{\text {a-e }}$ Means with different letters within the same column are significantly different $(\mathrm{p}<0.05)$.

and mixing time. In addition, the analysis of variance found statistically significant differences $(\mathrm{p} \leq 0.05)$ among treatments. The results found for the control treatments separated them into an independent group with values of almost $0 \%$; in control treatments, the small quantities obtained during centrifugation were distributed in thin layers over the pulp surfaces and of the walls of the tubes, making it difficult to recover the oil. For the rest of the tested conditions, intermediate yields were found. The highest values obtained with the procedures at 40 and $50{ }^{\circ} \mathrm{C}$ for 120 min were significantly superior to the other combinations of mixing times and temperatures. Equally long treatments have been recommended before, even with auxiliary technology; such is the case of Buelvas et al. (2012), who applied two hours of malaxation in the presence of enzymes and obtained oil extraction of $84.5 \%$ with "Lorena" variety avocados. Our results are similar and even superior. In our experiments, the extraction yield at $50{ }^{\circ} \mathrm{C}$ for $180 \mathrm{~min}$ malaxation decreased significantly compared with all the other treatments except the control. In contrast, at $40{ }^{\circ} \mathrm{C}$ for $180 \mathrm{~min}$, it was below the treatment with $120 \mathrm{~min}$. This reduction is due to a higher loss of moisture with $180 \mathrm{~min}$ of malaxation making extraction difficult. This was observed by Santana et al. (2011) during oil press extraction from avocado pulp subjected to malaxation and dehydration; they related a lower proportion of extracted oil to lower moisture contents and, thus, a reduction in porosity of the matrix and oil fluidization.

\subsection{Fatty acid profiles}

The normalized composition of fatty acids of virgin avocado oil obtained by applying diverse mixing times and temperatures is shown in Table 2. The most abundant FAs were oleic and palmitic, followed in descending order by linoleic, palmitoleic, linolenic and stearic acids. These data suggest that the broad variation in percentage in function of the treatment depended on the compound studied. Thus, the acids with variations above $10 \%$, in increasing order were linolenic (12.8\%), palmitoleic (13.1\%) and stearic (15.2\%), while the most stable were oleic, palmitic and linoleic $(1.5,5$ and $8.9 \%$, respectively). Relative to other edible oils, the experimental avocado oil included in this study is characterized by high percentages of monounsaturated fatty acids (oleic and palmitoleic), elevated of palmitic acid and a lower of stearic (saturated) acid (Table 3). According to our results, the normalized lipid profile described defined the obtained oils as high in oleic even though the percentages of palmitic acid are higher than in other oils, such as olive oil (Meyer \& Terry, 2008). Because of its high levels of oleic acid, avocado oil is considered to be very similar to olive oil.

According to normalized composition, percentages of saturated FAs, such as stearic acid, remained without change ( $p \geq 0.05$ ). But in the case of palmitic acid the differences relative to the control were statistically significant $(p \leq 0.05)$ in the longest treatments (120 and $180 \mathrm{~min}$ ), for which the highest percentages were quantified, regardless of the temperature used. The monounsaturated FAs studied had slight changes only in palmitoleic acid with significant, but unclear differences $(p \leq 0.05)$ between the control, treatment at $40^{\circ} \mathrm{C}$ for $40 \mathrm{~min}$ and the rest of treatments with percentages that oscillated between the treatments at $0 \mathrm{~min}$ and $40{ }^{\circ} \mathrm{C}$ during $60 \mathrm{~min}$. Thus, oleic acid remained without significant differences $(\mathrm{p} \geq 0.05)$. In the polyunsaturated FA studied such as linoleic acid (Table 2), there was no significant effect of temperature on the normalized percentage ( $p \geq 0.05)$, but the oil normalized profiles obtained with the longest malaxation times $(120$ and $180 \mathrm{~min})$ had lower $(\mathrm{p} \leq 0.05)$ percentages than the other mixing times tested. The normalized percentages of linolenic acid were higher in the oils extracted after malaxation at $40{ }^{\circ} \mathrm{C}$ for $60 \mathrm{~min}$, while extraction after malaxation at $40{ }^{\circ} \mathrm{C}$ for 120 min yielded the lowest percentage of this fatty acid. However, only this pair of treatments showed clear significant differences $(\mathrm{p} \leq 0.05)$ in the normalized linolenic acid percentage of the oil. The effect of time and temperature was the same as in the case of linoleic acid ( $\mathrm{p} \leq 0.05)$. Malaxation temperature and time have been reported as physical factors that influence oil oxidation. Temperature is the basic factor, while a longer malaxation time increases exposure to factors such as air and light (Kochhar \& Henry, 2009). Prolonged exposure to air and light produces deteriorative changes in the oil since oxidation occurs even at temperatures very close to ambient temperature $\left(30^{\circ} \mathrm{C}\right)$. Light and heat trigger the autoxidation chain reaction of unsaturated FA by supplying the energy required to activate their reaction with $\mathrm{O}_{2}$ and to generate the first radicals necessary for their propagation, which, without light and heat and despite the presence of air, is thermodynamically difficult (Naz et al., 2005).

Overall, the changes in the normalized percentage of FA of oils obtained under the different malaxation conditions studied, consisted of an increase in unsaturated fatty acids with mixing time and temperature $(\mathrm{p} \leq 0.05)$. The percentage of monounsaturated acids remained without alteration and there were slight increases $(p \geq 0.05)$ in palmitoleic acid. The percentage of polyunsaturated fats decreased $(p \leq 0.05)$ with mixing time. Linolenic acid was that which most decreased, followed by linoleic acid. The changes in the normalized fatty acid profile in our study coincide with 
Table 2. Fatty acid normalized profile in cold extracted avocado oil (Persea americana var. Hass) using different malaxation times and temperatures.

\begin{tabular}{|c|c|c|c|c|c|c|c|}
\hline \multicolumn{2}{|c|}{ Malaxation conditions } & \multicolumn{6}{|c|}{ Fatty acid percentage ${ }^{\mathrm{A}}(\%)$} \\
\hline $\begin{array}{c}\text { Temperature } \\
\left({ }^{\circ} \mathrm{C}\right)\end{array}$ & $\begin{array}{l}\text { Time } \\
(\min )\end{array}$ & $\begin{array}{l}\text { Palmitic } \\
(\mathrm{C} 16)\end{array}$ & $\begin{array}{l}\text { Stearic } \\
(\mathrm{C} 18)\end{array}$ & $\begin{array}{l}\text { Palmitoleic } \\
(\mathrm{C} 16: 1)\end{array}$ & $\begin{array}{l}\text { Oleic } \\
(\mathrm{C} 18: 1)\end{array}$ & $\begin{array}{c}\text { Linoleic } \\
(\mathrm{C} 18: 2 \mathrm{n}-6)\end{array}$ & $\begin{array}{l}\text { Linolenic } \\
(\mathrm{C} 18: 3 n-6)\end{array}$ \\
\hline \multirow{4}{*}{40} & $\mathbf{0}$ & $18.5 \pm 0.1^{\mathrm{a}}$ & $0.5 \pm 0.1^{\mathrm{a}}$ & $8.10 \pm 0.04^{\mathrm{a}}$ & $50.6 \pm 0.1^{\mathrm{a}}$ & $20.9 \pm 0.1^{\mathrm{e}}$ & $1.3 \pm 0.1^{\mathrm{bcd}}$ \\
\hline & 30 & $18.8 \pm 0.8^{\mathrm{ab}}$ & $0.4 \pm 0.1^{\mathrm{a}}$ & $9.6 \pm 0.8^{c}$ & $51.4 \pm 0.4^{\mathrm{a}}$ & $19 \pm 1^{\text {bcde }}$ & $1.2 \pm 0.2^{\mathrm{abc}}$ \\
\hline & 40 & $18.4 \pm 0.8^{\mathrm{a}}$ & $0.60 \pm 0.04^{\mathrm{a}}$ & $8.5 \pm 0.8^{\mathrm{ab}}$ & $51.6 \pm 0.4^{\mathrm{a}}$ & $20 \pm 1^{\mathrm{de}}$ & $1.4 \pm 0.1^{\mathrm{bcd}}$ \\
\hline & 180 & $19.5 \pm 1.6^{\mathrm{abc}}$ & $0.6 \pm 0.1^{\mathrm{a}}$ & $9.0 \pm 0.2^{\mathrm{abc}}$ & $52.4 \pm 1.7^{\mathrm{a}}$ & $17.5 \pm 3.3^{\mathrm{abcd}}$ & $1.1 \pm 0.2^{\mathrm{abcd}}$ \\
\hline \multirow[b]{4}{*}{50} & $\mathbf{0}$ & $18.5 \pm 0.1^{\mathrm{a}}$ & $0.5 \pm 0.1^{\mathrm{a}}$ & $8.10 \pm 0.04^{\mathrm{a}}$ & $50.6 \pm 0.1^{\mathrm{a}}$ & $20.9 \pm 0.1^{\mathrm{e}}$ & $1.3 \pm 0.1^{\mathrm{bcd}}$ \\
\hline & 20 & $19.5 \pm 0.2^{\mathrm{abc}}$ & $0.6 \pm 0.1^{\mathrm{a}}$ & $9.8 \pm 0.1^{c}$ & $50.7 \pm 0.5^{\mathrm{a}}$ & $18.0 \pm 0.1^{\mathrm{bcd}}$ & $1.3 \pm 0.2^{\mathrm{bcd}}$ \\
\hline & 30 & $19.4 \pm 0.1^{\mathrm{a}}$ & $0.5 \pm 0.1^{\mathrm{a}}$ & $9.7 \pm 0.1^{c}$ & $51.2 \pm 0.5^{\mathrm{a}}$ & $18.1 \pm 0.1^{\text {bcde }}$ & $1.2 \pm 0.1^{\mathrm{bcd}}$ \\
\hline & 40 & $19.8 \pm 0.4^{\mathrm{ab}}$ & $0.6 \pm 0.1^{\mathrm{a}}$ & $9.6 \pm 0.3^{c}$ & $51.3 \pm 0.6^{\mathrm{a}}$ & $18.1 \pm 0.2$ & $1.10 \pm 0.04^{\mathrm{abc}}$ \\
\hline
\end{tabular}

${ }^{\mathrm{A}}$ Values are expressed as normalized percentages and are the means \pm SD $(\mathrm{n}=3)$; ${ }^{\text {a-e }}$ Means with different letters within the same column are significantly different $(\mathrm{p}<0.05)$.

Table 3. Normalized saturated and unsaturated fatty acids percentages in cold extracted avocado oil (Persea americana var. Hass) using different malaxation times and temperatures.

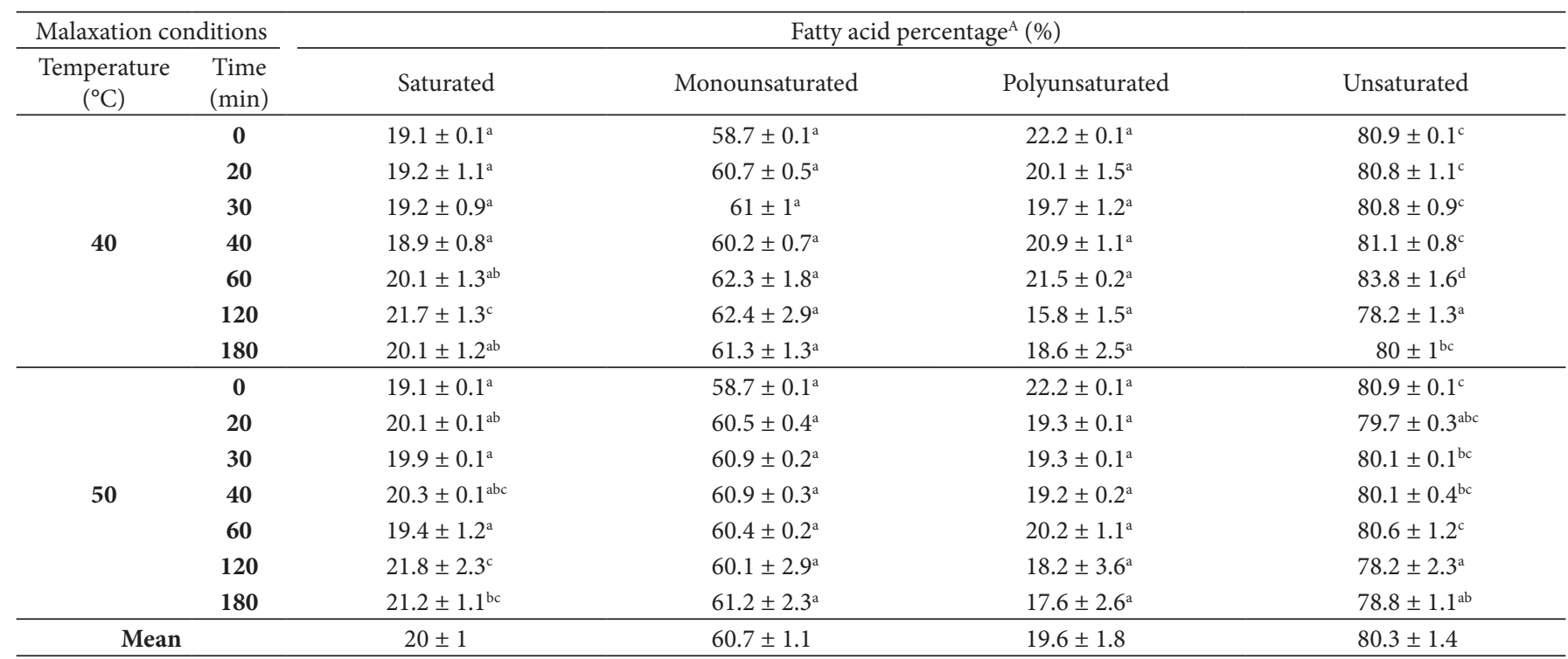

${ }^{\mathrm{A}}$ Values are expressed as normalized percentages and are the means \pm SD $(\mathrm{n}=3)$; ${ }^{\mathrm{a}-\mathrm{c}}$ Means with different letters within the same column are significantly different $(\mathrm{p}<0.05)$.

those reported by Bešter et al. (2008), who used more severe treatment conditions (frying temperatures) in their study on stability of extra virgin olive oils. Although the normalized analytical data is a way of expression frequently used in a large number of papers, the disadvantage is that in oils and fats heated at frying temperatures the relative fatty acid methyl ester (FAME) composition given is that of the non-altered FAME fraction, which is the only one eluted in the GC analysis, and oxidized FAME are not quantified because they are adsorbed in the column because of their high polarity (Dobarganes \& Márquez-Ruiz, 2007). Table 4 shows the adjusted percentages on the eluted fractions of non-oxidized FAME in experimental avocado virgin oils. These percentages were calculated using the procedure proposed by Berdeaux et al. (2012), which considers the major saturated fatty acid (palmitic) unchanged in order to measure indirectly the thermoxidative FAME alteration.

There were variations of more than $10 \%$ in the adjusted data for linoleic (16.1\%) and linolenic (13.4\%) acids. However, oleic and palmitoleic acids were more stable ( 2 and $6.3 \%$, respectively). The variations in percentages of stearic acid on the eluted fractions of non-oxidized FAME in the different combinations of malaxation time and temperature studied were not significant $(\mathrm{p} \geq 0.05)$. Regarding the monounsaturated fatty acids, we confirmed a reduction in the percentage of oleic acid in the eluted fraction of the oil from longer treatments (120 and 
$180 \mathrm{~min})$; the highest percentages were found in the time treatments of 20,30 , and $40 \mathrm{~min}$ at $40{ }^{\circ} \mathrm{C}(\mathrm{p} \leq 0.05)$. The same trend was observed with palmitoleic acid, although in this case the temperature increase did not cause significant effects $(p \geq 0.05)$. The polyunsaturated fatty acids followed the same trend; that is, significantly lower concentrations resulted at longer times (120 and $180 \mathrm{~min}$ ), but with higher losses of linoleic acid. However, these fatty acids were not significantly affected by temperature $(p \geq 0.05)$. Most of the changes observed in the adjusted data of virgin avocado oil (Table 4) are similar to those described for sunflower seed oil and olive oil at frying conditions (temperatures of $180^{\circ} \mathrm{C}$ during $0,5,10$ and $15 \mathrm{~h}$ ) (Berdeaux et al., 2012). Is very well known that polyunsaturated fatty acids oxidize earlier than monounsaturated, and saturated fatty acids do not oxidize. Frankel (1985) showed rates of relative oxidation of stearic, oleic, linoleic and linolenic acids of 1, 100, 1200 and 2500, respectively, and the rate of oxidation increased with increases in the number of double bonds.

\section{4 $\omega-6: \omega-3$ ratio (nutritional assessment)}

In our study, we calculated the ratio of $\omega-6: \omega-3$ from the normalized FA percentages of the linoleic $(\omega-6)$ and linolenic $(\omega-3)$. The values for the experimental oils were found within a very narrow range that oscillated between 13.5:1 \pm 1.3 and 17:1 \pm 3.3 (Table 5), with no significant differences among the treatments, mixing times or temperatures studied ( $\mathrm{p} \geq 0.05)$. Massafera et al. (2010), who studied the FA composition in oils from pulp of different avocado cultivars in a region of Brazil, reported similar low ratios of 7.7:1, 7.1:1 and 12:1 in oil obtained from the cultivars Fortuna, Oro Verde and Princesa, respectively. From a nutritional perspective, the balance between daily input of food sources of $\omega-6$ and $\omega-3$ fatty acids is important since a lower ratio of $\omega-6$ to $\omega-3$ is desirable to reduce the risk of diverse chronic diseases that are highly prevalent in western society and are becoming increasingly present worldwide. The ratios we found are above the near 1 values in the ratios of the diet with which man evolved (Simopoulos, 2004). They are also higher than those recommended for optimum transformation of linoleic acid into very long-chained polyunsaturated fatty acids (4:1 to 5:1) and above that which favors greater conversion of alpha-linolenic acid into $\omega-3$ acids (2:1 to 3:1) (Martin et al., 2006). However, they are within the ratios reported for different countries, which recently have oscillated between 10:1 to 20:1, but with records of up to 50:1 (Simopoulos, 2004).

\subsection{Linoleic:palmitic ratio (C18:2 n-6/C16:0)}

The linoleic:palmitic ratios obtained in our study were between $0.70 \pm 0.02\left(40^{\circ} \mathrm{C}\right.$ for $120 \mathrm{~min}$ ) and $1.10 \pm 0.01$ (control). The highest value (1.1) was calculated in the oil from pulp that was not exposed to any of the treatment conditions, while the lowest ratios were obtained in oils extracted with the longest malaxation times, 120 and $180 \mathrm{~min}(\mathrm{p} \leq 0.05)$ (Table 5). We also observed that the treatments conducted at $50^{\circ} \mathrm{C}$ tended to have ratios lower than those conducted at $40{ }^{\circ} \mathrm{C}$, but variations were not statistically significant in any case $(\mathrm{p} \geq 0.05)$. When a fat or oil is exposed to heat, the linoleic acid/palmitic acid ratio decreases because oxidation decomposes linoleic acid. This ratio is considered an indicator of fat or oil deterioration. The lack of significant changes may be attributed to the lower temperatures assayed despite the long malaxation times. Other studies in edible oil conducted at higher temperatures have reported similar but significant changes associated to intense thermo-oxidative transformations produced in heated oil-containing food (Alireza et al., 2010), and in olive oil subjected to temperature increases in the frying range (Navas, 2007).

Table 4. Adjusted fatty acid methyl ester profile of the eluted fraction in cold extracted avocado oil (Persea americana var. Hass) using different malaxation times and temperatures.

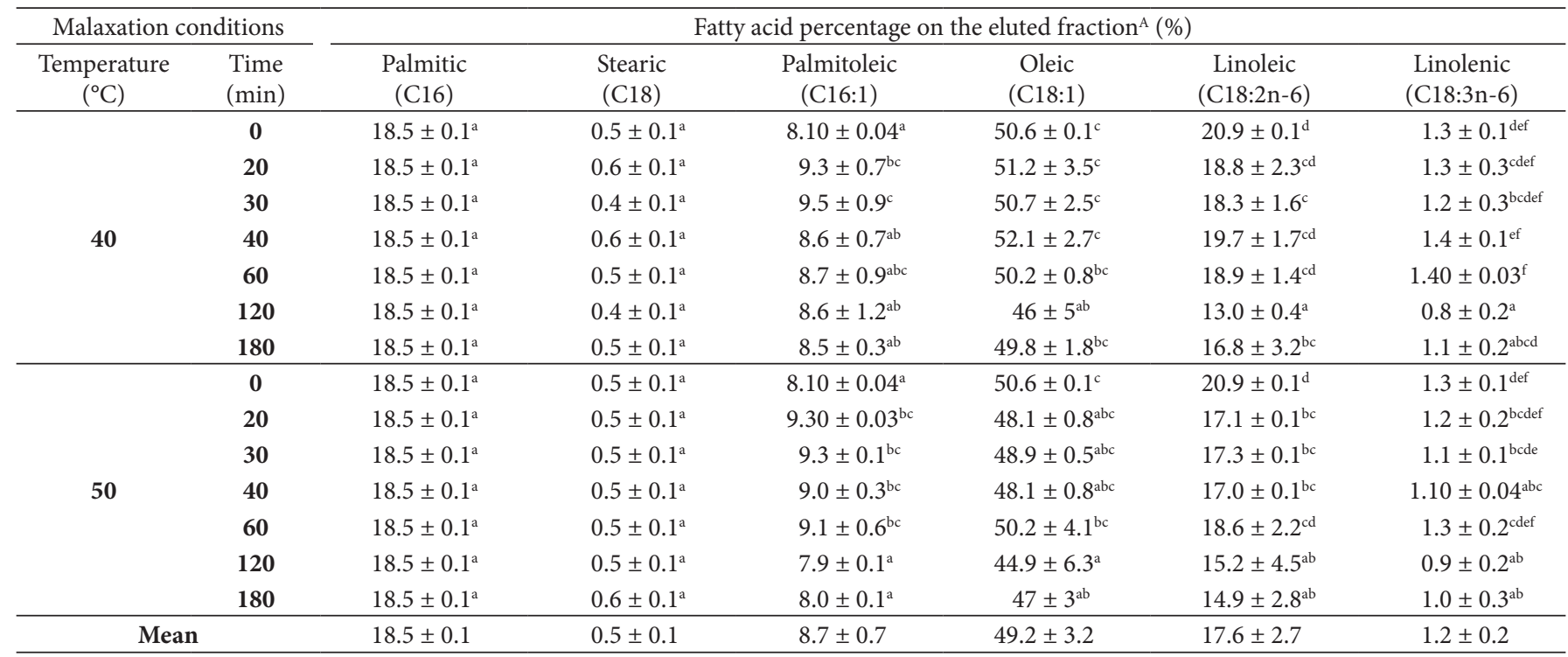

${ }^{\mathrm{A}}$ Values are expressed as adjusted percentages on non-oxidized FAME and are the means \pm SD $(\mathrm{n}=3)$; ${ }^{\text {a-f }}$ Means with different letters within the same column are significantly different $(\mathrm{p}<0.05)$. 
Table 5. Nutritional and oxidative parameters in cold extracted avocado oil (Persea americana var. Hass) using different malaxation times and temperatures.

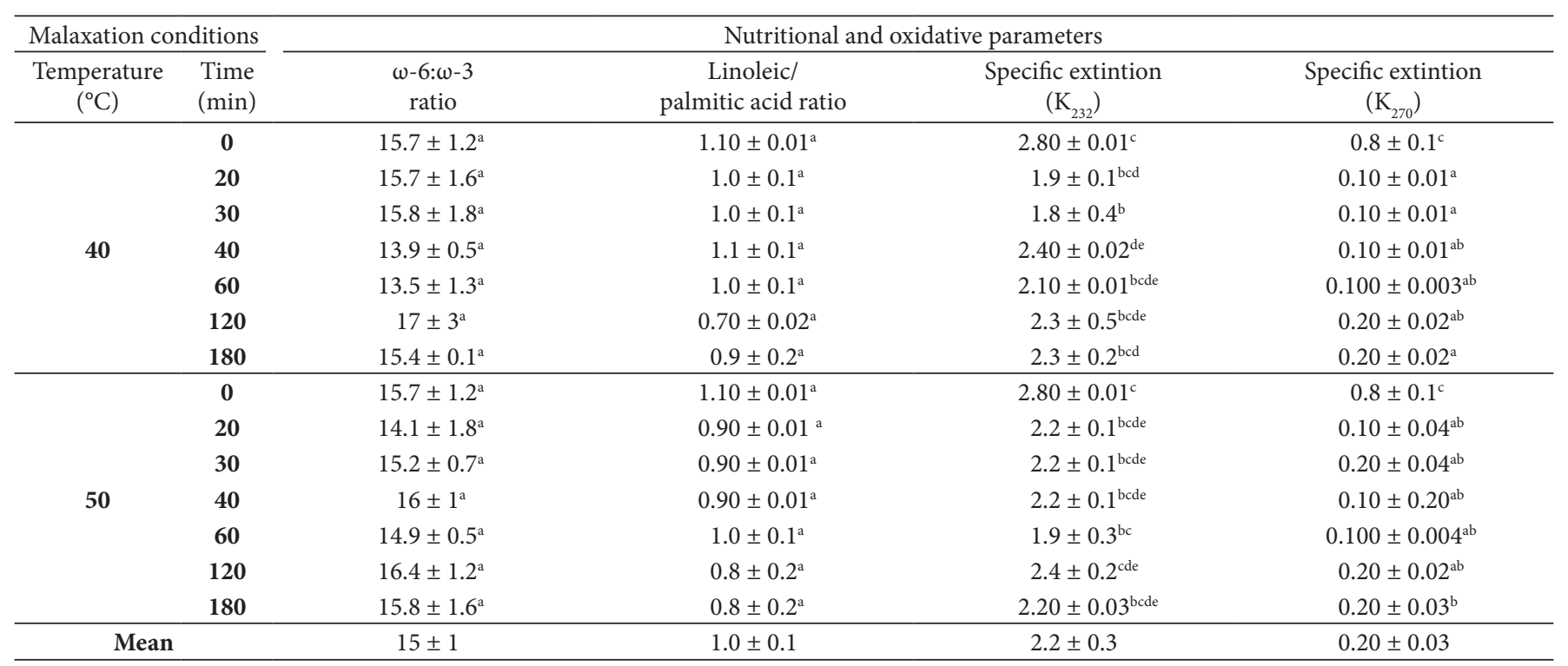

Values are the means \pm SD $(n=3)$; a-e Means with different letters within the same column are significantly different $(\mathrm{p}<0.05)$.

\subsection{Specific extinction $\left(K_{270} Y K_{232}\right)$}

The analysis of variance of specific extinction values at $232 \mathrm{~nm}$ found statistically significant differences $(p \geq 0.05)$ among the tested treatments (Table 5). The lowest, quantified in oils from the treatments at $40{ }^{\circ} \mathrm{C}$ for $30 \mathrm{~min}$ and $50{ }^{\circ} \mathrm{C}$ for $60 \mathrm{~min}$, were clearly differentiated from the highest, which corresponded to the treatments with no malaxation, while the rest of the oils were grouped in a single set. Analysis of the specific extinctions at $270 \mathrm{~nm}$ showed lower estimations for the treatments at $40{ }^{\circ} \mathrm{C}$ for 20 and $30 \mathrm{~min}$, which separated from those quantified in the treatments without malaxation. Pastore et al. (2014) conducted a study on extra virgin olive oil obtained by centrifugation applying different levels of environmental oxygen during malaxation and reported low specific extinctions at $232 \mathrm{~nm}$ and $270 \mathrm{~nm}$ (1.7 and 1.9, respectively). In our experiments, the index at $232 \mathrm{~nm}$ of all the treatments surpassed those obtained by the above mentioned study, except in the oils obtained at $40{ }^{\circ} \mathrm{C}$ with $20,30,40$ and $60 \mathrm{~min}$ mixing times and at $50{ }^{\circ} \mathrm{C}$ with 20 and 40 min mixing times. In the case of the treatments with no malaxation ( $0 \mathrm{~min})$, it was possible to obtain oil only from fruits over-ripened in postharvest. This condition of the raw material originated the elevated $\mathrm{K}_{232}$ and $\mathrm{K}_{270}$ calculated in these oils. The same results were observed in the case of oil extracted from olives in this state of maturation (Fuentes de Mendoza et al., 2013). Our experimental avocado oils showed a low index of conjugated hidroperoxides (K232) according to the European Union standards for extra virgin olive oil quality (Unión Europea, 2011). The exception was the oil from the control treatments (Table 5). According to the estimates of specific extinction at $270 \mathrm{~nm}$, all the coefficients calculated were low. The $\mathrm{K}_{232}$ and $\mathrm{K}_{270}$ estimates (Table 5) showed no differences among malaxation temperatures, but there were differences among malaxation times ( $\mathrm{p} \geq 0.05)$. These results indicate that in the experimental oils the oxidation levels remained low and that the shortest malaxation times resulted in lower estimations $(\mathrm{p} \leq 0.05)$. Again, the exceptions were the control treatments.

\subsection{Oil yield and quality analysis}

From the results discussed above, we can confirm that the highest proportion of oil was extracted with the treatments that included malaxation at $50{ }^{\circ} \mathrm{C}$ for $120 \mathrm{~min}$. However, the treatments whose malaxation conditions were $50{ }^{\circ} \mathrm{C}$ for 30 and $60 \mathrm{~min}$ had equivalent yields, lower but not statistically different ( $\mathrm{p} \geq 0.05$ ). The use of shorter malaxation times would be an improvement for the process since it would speed up extraction. However, the treatments with 30 and 60 min malaxation were also equivalent to those treatments in which the lowest proportion of oil was recovered ( $p \geq 0.05$ ). Moreover, the treatments with higher extraction percentages preserved high proportions of monounsaturated FA (oleic and palmitoleic) $(\mathrm{p} \leq 0.05)$, the smallest proportions of linoleic acid and, in the case of the treatment at $40{ }^{\circ} \mathrm{C}$ for $120 \mathrm{~min}$, of linolenic acid ( $\mathrm{p} \leq 0.05$ ). Although there were small proportions of $\omega-6: \omega-3 \mathrm{FA}$, there were no statistical differences in the nutritional quality index of the oils studied ( $p \geq 0.05$ ), which were within a narrow range of values and, overall, were low and equivalent to those reported in other studies (Massafera et al., 2010). For this reason, we consider the proportion of linoleic acid, relative to that of linolenic acid, is favorable for health in all the cases analyzed regardless of the malaxation temperature used. The oxidative effect on the normalized FA profile, measured as the proportion of linoleic acid to palmitic acid, was a more marked reduction with increased malaxation times ( $p \geq 0.05$ ), but not with the tested temperatures. However, the coefficients of absorption in the ultraviolet region $\left(\mathrm{K}_{232}\right.$ and $\left.\mathrm{K}_{270}\right)$ indicated that the oxidation level of avocado virgin oil remained low. Thus, the 120 min malaxation time improved oil extraction yields from Mexican Hass avocados and using temperatures of 40 or $50^{\circ} \mathrm{C}$ equally contribute to an adequate nutritional profile. 


\section{Conclusions}

Malaxation under the conditions studied induced changes in yield of virgin avocado (Persea americana Mill) oil extracted by centrifugation from Mexican Hass avocados, in its normalized fatty acid profile, nutritional quality and oxidation state. Despite the variations, all the oils obtained conserved the fatty acid profile characteristic of high oleic acid oils. The $\omega-6: \omega-3$ ratio was low, and corresponded to the values of mean intake worldwide. The specific extinctions indicated that the oxidation level of avocado virgin oil remained low. However, the malaxation treatments at 40 and $50{ }^{\circ} \mathrm{C}$ for $120 \mathrm{~min}$ were those that obtained the highest extraction yield as well as adequate nutritional quality associated to its lipid profile.

\section{Acknowledgements}

This research was funded by PROMEP/SEP, Mexico DSA/103.5/14/11116.

\section{References}

Alireza, S., Tan, C., Hamed, M., \& Che, M. Y. (2010). Effect of frying process on fatty acid composition and iodine value of selected vegetable oils and their blends. International Food Research Journal, 17, 295-302.

Alvizouri, M. M., \& Rodríguez, B. A. (2009). Efectos médicos del aguacate. Medicina Interna de México, 25, 379-386.

Ariza, O. J. A., López, V. F., Coyotl, H. J., Ramos, C. M. E., Díaz, R. J., \& Martínez, Z. A. (2011). Efecto de diferentes métodos de extracción sobre el perfil de ácidos grasos en el aceite de aguacate (Persea americana Mill. var. Hass). Revista Venezolana de Ciencia y Tecnología de Alimentos, 2, 263-276.

Association of Official Analytical Chemists - AOAC. (2007). Official methods of analysis hod. 17th ed. Maryland: AOAC.

Berasategi, I., Barriuso, B., Ansorena, D., \& Astiasarán, I. (2012). Stability of avocado oil during heating: Comparative study to olive oil. Food Chemistry, 132(1), 439-446. PMid:26434313. http://dx.doi. org/10.1016/j.foodchem.2011.11.018.

Berdeaux, O., Marmesat, S., Velasco, J., \& Dobarganes, M. C. (2012). Apparent and quantitative loss of fatty acids and triacylglycerols at frying temperatures. Grasas y Aceites, 63(3), 284-289. http://dx.doi. org/10.3989/gya.034412.

Bešter, E., Butinar, B., Bučar-Miklavčič, M., \& Golob, T. (2008). Chemical changes in extra virgin olive oils from Slovenian Istra after thermal treatment. Food Chemistry, 108(2), 446-454. PMid:26059121. http:// dx.doi.org/10.1016/j.foodchem.2007.10.061.

Buelvas, S. G. A., Patiño, G. J. H., \& Cano-Salazar, J. A. (2012). Evaluación del proceso de extracción de aceite de aguacate hass (Persea americana Mill) utilizando tratamiento enzimático. Revista Lasallista de Investigación, 9, 138-150.

Costagli, G., \& Betti, M. (2015). Avocado oil extraction processes: method for cold-pressed high-quality edible oil production versus traditional production. Journal of Agricultural Engineering, 46(3), 115-122. http://dx.doi.org/10.4081/jae.2015.467.

Ding, H., Chin, Y. W., Kinghorn, A. D., \& D’Ambrosio, S. M. (2007). Chemopreventive characteristics of avocado fruit. Seminars in Cancer Biology, 17(5), 386-394. PMid:17582784. http://dx.doi.org/10.1016/j. semcancer.2007.04.003.
Dobarganes, M. C., \& Márquez-Ruiz, G. (2007). Formation and analysis of oxidized monomeric, dimeric and higher oligomeric triglycerides. In. M. D. Erickson (Ed.), Deep frying: chemistry nutrition and practical applications (pp. 87-110). Champaign: AOCS Press. http://dx.doi. org/10.1016/B978-1-893997-92-9.50012-8.

Frankel, E. N. (1985). Chemistry of autoxidation: mechanism, products and flavor significance. In D. B. Min \& T. H. Smouse (Eds.), Flavor chemistry of fats and oils (Chap. 1, pp. 1-37). Champaign: AOCS Press.

Fuentes de Mendoza, M., De Miguel Gordillo, C., Marín Expóxito, J., Sánchez Casas, J., Martínez Cano, M., Martín Vertedor, D., \& Franco Baltasar, M. N. (2013). Chemical composition of virgin olive oils according to the ripening in olives. Food Chemistry, 141(3), 2575-2581. PMid:23870997. http://dx.doi.org/10.1016/j.foodchem.2013.05.074.

Guardiola, F., Codony, R., Rafecas, M., Boatella, J., \& Lopez, A. (1994). Fatty acid composition and nutritional value of fresh eggs from large- and small-scale farms. Journal of Food Composition and Analysis, 7(3), 171-188. http://dx.doi.org/10.1006/jfca.1994.1017.

International Olive Council - IOC. (2015). Spectrophotometric investigation in the ultraviolet. Madrid: IOC. COI/T.20/Doc. No 19/Rev.3.

Kochhar, S. P., \& Henry, C. J. (2009). Oxidative stability and shelf-life evaluation of selected culinary oils. International Journal of Food Sciences and Nutrition, 60(Suppl 7), 289-296. PMid:19634067. http:// dx.doi.org/10.1080/09637480903103774.

Martin, C. A., Almeida, V. V., Ruiz, M. R., Visentainer, J. E. L., Matshushita, M., Souza, N. E., \& Visentainer, J. V. (2006). Ácidos graxos poli-insaturados ômega-3 e ômega-6: importância e ocorrência em alimentos. Revista de Nutrição, 19(6), 761-770. http://dx.doi. org/10.1590/S1415-52732006000600011.

Massafera, G., Braga, C. T. M., \& Dutra, J. E. O. (2010). Composição de ácidos graxos do óleo do mesocarpo e da semente de cultivares de abacate (Persea americana Mill.) da Região de Ribeirão Preto, SP. Revista Alimentos e Nutrição, 21, 325-331.

Meyer, M. D., \& Terry, L. A. (2008). Development of a rapid method for the sequential extraction and subsequent quantification of fatty acids and sugars from avocado mesocarp tissue. Journal of Agricultural and Food Chemistry, 56(16), 7439-7445. PMid:18680299. http:// dx.doi.org/10.1021/jf8011322.

Navas, S. (2007). Optimization of analytical methods for the assessment of the quality of fats and oils used in continuous deep fat frying. Grasas y Aceites, 58, 148-153.

Naz, S., Siddiqi, R., Sheikh, H., \& Sayeed, S. A. (2005). Deterioration of olive, corn and soybean oils due to air, light, heat and deepfrying. Food Research International, 38(2), 127-134. http://dx.doi. org/10.1016/j.foodres.2004.08.002.

Oliveira, M. C., Pio, R., Ramos, J. D., Lima, L. C. O., Pasqual, M., \& Santos, V. A. (2013). Fenología e características físico-químicas de frutos de abacateiros visando à extraçâo de óleo. Ciência Rural, 43(3), 411-418. http://dx.doi.org/10.1590/S0103-84782013000300006.

Pastore, G., D’Aloise, A., Lucchetti, S., Maldini, M., Moneta, E., Peparaio, M., Raffo, A., \& Sinesio, F. (2014). Effect of oxygen reduction during malaxation on the quality of extra virgin olive oil (Cv. Carboncella) extracted through "two-phase" and "three-phase" centrifugal decanters. Lebensmittel-Wissenschaft + Technologie, 59(1), 163-172. http://dx.doi.org/10.1016/j.lwt.2014.04.053.

Restrepo, D. A. M., Londoño-Londoño, J., González, A. D., Benavides, P. Y., \& Cardona, S. B. D. (2012). Comparación del aceite de aguacate variedad Hass cultivado en Colombia, obtenido por fluidos supercríticos y métodos convencionales: una perspectiva desde la calidad. Revista Lasallista de Investigación, 9, 151-161. 
Santana, I., Cabral, L. M. C., Freitas, S. P., \& Torres, A. G. (2011). Efeito do prétratamento na extração do óleo da polpa de abacate Hass (Persea americana). In Anais do II Congresso Brasileiro de Processamento de Frutas e Hortaliças: Alimentação Inteligente com Tecnologia Limpa. Rio de Janeiro: Sociedade Brasileira de Processamento de Frutas e Hortaliças.

Schwartz, M., Olaeta, J. A., Undurraga, P., \& Costa, V. (2007). Mejoramiento del rendimiento de extracción del aceite de palta (Aguacate). In Proceedings VI World Avocado Congress. Viña Del Mar, Chile.

Simopoulos, A. P. (2004). Omega-6/Omega-3 essential fatty acid ratio and chronic diseases. Food Reviews International, 20(1), 77-90. http://dx.doi.org/10.1081/FRI-120028831.

Unión Europea - UE. (2011). Relativo a las características de los aceites de oliva y de los aceites de orujo de oliva y sobre sus métodos de análisis (Reglamento (UE) No. 61/2011 de la Comisión que modifica el Reglamento (CEE) no. 2568/91). Official Journal of the European Union.

Villa-Rodríguez, J. A., Molina-Corral, F. J., Ayala-Zavala, J. F., Olivas, G. I., \& González-Aguilar, G. A. (2011). Effect of maturity stage on the content of fatty acids and antioxidant activity of 'Hass' avocado. Food Research International, 44(5), 1231-1237. http://dx.doi.org/10.1016/j. foodres.2010.11.012.

Woolf, A., Wong, M., Eyres, L., McGhie, T., Lund, C., Olsson, S., Wang, Y., Bulley, C., Wang, M., Friel, E., \& Requejo-Jackman, C. (2009). Avocado oil. In R. A. Moreau \& A. Kamal-Eldin (Eds.), Gourmet and health-promoting specialty oils (Chap. 2, pp. 73-125). Urbana: AOCS Press. http://dx.doi.org/10.1016/B978-1-89399797-4.50008-5. 